\title{
PHILLIP CAGAN*
}

\section{Imported Inflation 1973-74 and the Accommodation Issue}

\section{INTRODUCTION}

\section{A. Proposals for Monetary Accommodation of Imported Inflation}

A SUBSTANTIAL PART of the escalation of inflation in 1973 and 1974 was attributed to foreign influences. Crop failures abroad put pressure on limited world supplies of grains and soybeans. The synchronous expansion of many industrial economies increased the demand for basic metals. And the OPEC oil cartel quadrupled the price of crude petroleum. U.S. wholesale prices of the manufacturing sector as measured here rose 17 percent per year in 1973 and 1974 .

To the extent that such major price increases were due to foreign influences, it appeared that they could not be immediately prevented by domestic monetary restraint. This traditional policy response to escalating inflation appeared somehow inappropriate, and the Federal Reserve was urged to "accommodate" the foreign-induced price increases, that is, supply the monetary growth needed to sustain the higher prices resulting from foreign influences $[13,15,17] .^{1}$ If, instead,

\footnotetext{
*Financial support for this study to the National Bureau of Economic Research from the U.S. Department of Labor and National Science Foundation is gratefully acknowledged. Any opinions. findings. conclusions. or recommendations expressed herein are those of the author and do not necessarily reflect the views of the department or the foundation. I am indebted to Robert E. Lipsey for helpful comments and to Susan Tebbetts for research assistance.

This report has not undergone the review accorded official NBER publications; in particular, it has not been submitted for approval to the Board of Directors.

'To the extent that some price increases of imported goods, such as petroleum. substantially raised costs of production in real terms, total domestic output would be less, and less money was required. For an estimate of the reduction in output. see [16].
}

PHILlIP CAGAN is professor of economics, Columbia University, and research associate, National Bureau of Economic Research.

0022-2879/80/0280-0001\$00.50/0 $\quad$ C 1980 Ohio State University Press

Jolrnal of MONEY, Credit, AND Banking, vol, 12, no. 1 (February 1980) 
monetary restraint were to put downward pressure on all domestic prices until the foreign-induced increases in the domestic price level were reversed, the pressure would produce a prolonged period of economic slack and reduced output. The proper conduct of monetary policy in the face of such developments remains an unsettled issue.

What was the difference between price increases due to foreign influences and those due to domestic excess demand that allegedly called for accommodation in the former case and traditional monetary restraint in the latter? lt could not be simply that foreign demands for U.S. goods had increased, as might happen if the rate of inflation abroad exceeded the domestic rate or if foreign demands shifted to particular U.S. products. For monetary restraint is intended and traditionally used to stabilize aggregate demand for domestic output from whatever source, and in this case the restraint would be aided by its tendency to appreciate the dollar exchange rate and thus to moderate the foreign demands and cheapen imports. Policymakers might, of course, err in the attempt to stabilize fluctuations in aggregate demand and then have to decide whether to continue to accommodate undesired movements in the price level, but that decision arises with any destabilizing change in aggregate demand and is not particular to foreign influences.

Furthermore, a policy of accommodation would be inappropriate if previous monetary expansion had produced domestic inflationary pressures that were causing the exchange rate to depreciate and dollar prices of imports to rise to match the advance in domestic prices. For then the price increases and the consequent depreciation of the exchange rate reflect a monetary expansion that has already occurred, and further expansion to accommodate lagging price increases is not needed to sustain aggregate output.

The argument for accommodation in 1973-74, as I understand it, pertained to prices of input materials determined in world markets. The OPEC cartel increased the dollar price of crude petroleum and so raised costs to producers of petroleum products. The world demand for grains and soybeans raised their dollar prices. These influences on prices of world-traded goods were direct-in contrast to indirect effects on U.S. aggregate demand and prices which international developments can induce through changes in domestic income or money supply. To be sure, some world developments may have no effect on U.S. prices because an accompanying change in the exchange rate leaves the average dollar price of imports and exports unchanged. But that did not happen in 1973 or later. One reason was that the volume of both imports and exports increased, to that extent canceling their separate effects on the exchange rate; and another reason was that petroleum imports were associated with short-term capital imports, substantially reducing the effect on the exchange rate. As a result, U.S. prices of many world-traded materials rose sharply and increased the costs of using them to manufacturing industries.

An important part of the accommodation proposal is the belief that monetary restraint cannot prevent world price increases from initially passing through to 
output prices. ${ }^{2}$ To some extent the escalation of inflation due to foreign influences elicits an increase in expenditures; the temporary response to sudden price increases is to spend more and to undertake the required cutbacks gradually. Even though aggregate expenditures will be determined by monetary growth in the long run, the private economy can partially support higher prices in the short run by a temporary rise in monetary velocity. But the accommodation proposal does not rest on such a difference between long-run and short-run behavior. The crucial supposition of the proposal is that exogenous increases in costs pass rapidly through to output prices. To the extent that aggregate expenditures are deficient, the cost-induced price increases produce a decline in goods sold and output. If policy does not accommodate the world price increases, they must eventually be offset by decreases in prices of other goods to achieve the price level consistent with aggregate demand. Given an ongoing rate of inflation, the offset does not require prices to decline but only to rise less rapidly. Demand pressure to reduce the rate of increase of prices is eventually successful, but it works slowly and requires a prolonged period of slack demand and reduced output.

A policy of accommodation is therefore based on the apparent asymmetry of price response, in which supply effects on prices occur rapidly and demand effects-at least for many industries-occur slowly. ${ }^{3}$ If this difference in timing did not exist, the absence of monetary accommodation should largely nullify the inflationary effects of exogenous cost increases when they occur or shortly afterward. The reasons for such asymmetry are not clear. Although demand shifts are hard to identify and may tend to be disregarded until with time the lasting shifts become apparent, prices of many materials are highly variable and the permanence of changes is also uncertain. Perhaps the difference between demand and supply effects in many industries is that demand effects may or may not cover the entire industry, whereas supply effects generally do, and that producers make price adjustments readily when they believe competitors are similarly affected and not otherwise.

In any event, the escalation of U.S. inflation in 1973 and 1974 was led by world-traded goods and the products made from them. Monetary growth was reduced and the usual signs of a tight monetary policy appeared, reflecting an unusually sharp decline in the real value of money balances due to slower monetary growth and higher inflation. The recession of 1973-75 produced appreciable slack in the economy but, from all appearances, did not reverse the higher level of prices

\footnotetext{
${ }^{2}$ This ignores the crucial role of expectations held by the public about future price movements and about the response of monetary policy. If it were believed that monetary growth would remain constant. this would influence the expected long-run path of prices which, in turn, would influence short-run price movements.

${ }^{3}$ An increase in the world price for an exported product has both demand and supply effects. of course, The domestic price is raised from the demand side, and this in turn increases the costs to firms using the product as an input. In addition. the increase in foreign demand may increase domestic incomes and affect international financial fows. No precise definition of different effects is intended here.

A separate question is whether there is asymmetry between price increases and decreases, which we do not address. See Goldstein [9], who found mixed indications of such asymmetry for the United States
} 
resulting from the 1973-74 escalation. The recession, though severe, removed only the blip in the rate of inflation, reducing it to consistency with the average rate of monetary growth. The runup in the level of prices had apparently been partially accommodated, whether intentionally or not, by a reduction in output, a speedup in monetary growth in 1975 and after, and an increase in monetary velocity $[5,10]$.

The purpose of the present study is to measure the amount of price increase that the proposals for accommodation required in 1973-74. Presumably such an estimate of the amount could be made in time to act on it. Whether accommodation is a desirable policy is not addressed here. Consistently followed, it would result in a higher long-run rate of inflation, because there are not likely to be nearly enough episodes of deflationary accommodation to offset the inflationary ones. Notwithstanding the appeal in the short run to accept inflationary fait accompli in order to avoid prolonged economic slack, one may have strong reservations about the long-run consequences on expectations of following such a policy.

\section{B. The Measurement of Imported Inflation}

Most previous studies of foreign influences in 1973-74 are based on time-series regressions of aggregate data. The U.S. inflation rate is regressed on a set of independent variables including a proxy for domestic aggregate demand and the rate of change of U.S. import prices. The latter variable is intended to represent exogenous foreign influences. The studies generally find that import prices account for around half of the U.S. inflation rate in $1973-74 .{ }^{4}$ These regression estimates incorporate all the influences correlated with import prices and do not distinguish among the possible sources. It is left unclear whether the estimated influence includes a rise in the cost of imported materials, a rise in export prices that affected input materials and final products, and a substitution effect and feedback of such price increases on other prices and wages. A policy of accommodating imported inflation would not necessarily intend to cover all such increases.

An alternative method of estimation is to focus on foreign increases in the cost of input materials. One such study by Federal Reserve economists [1] estimated the effect on industry input costs of the 1971 devaluation of the dollar and additional increases in prices (actually, unit values) of imports, and derived from the input-output matrix the corresponding increase in the price index of personal

\footnotetext{
${ }^{4}$ Various studies from which such estimates can be readily derived have come to my attention. (1) Weintraub [18. Tabies 10 and 11 , pp. 30-31] finds that an import price variable accounts for 44 percent of the increase in consumer prices 1973-74. (2) Modigliani and Papademos [13. p. 10] find that variables for farm and import prices combined account for 60 percent of the increase in consumer prices excluding food in 1974. (3) Dewald and Marchon [7, p. 38] find that import prices account for 46 percent of the increase in the GNP deflator 1973-74. (4) Keran and Riordan [1], pp. 10-11] find that dollar export prices of industrial countries have a regression coefficient of 0.16 in an equation explaining consumer price changes and of 0.41 in an equation explaining wholesale price changes. If these coefficients are applied to the rate of increase of the world-traded input price index for 1973-74 in Table 1, the induced increase in 1973-74 in consumer prices is 5.7 percent per year and in wholesale prices is 14.7 percent per year. These are 54 and 86 percent. respectively. of the actual increase in the consumer price index and in the manufacturing index of Table 1. (5) Levy $[12$, p. 33] attributes "roughly 60 percent" of inflation in the GNP deflator from second half of 1971 to second half of 1974 to international shocks. (6) Fair 18 , p. 31] reports an "impact effect" of import prices on the private nonfarm deflator of about one-quarter in 1973-74 but a long-run effect much greater
} 
consumption. They found that 28 percent of the increase in personal consumption prices from third-quarter 1971 to second-quarter 1974 was due to these foreign influences. That is about half of the effect found by regression methods. What accounts for the difference? Since the Fed study excluded increases in export prices and was based on other assumptions, there are a variety of possible explanations, not to mention a possible overestimate by the regression studies. ${ }^{5}$

The present study provides another estimate to clarify these questions. It is also based on the cost of input materials and the input-output matrix, but includes input materials that are partly exported and selects those affected by foreign influences in a different way. The Fed study covered all imports and attributed their rise in unit value to foreign influences. Here we derive for each input material the fraction of total domestic supply that is imported or exported, and those of 20 percent or more are assumed to have their prices determined entirely abroad and those less than 20 percent, entirely domestically. ${ }^{6}$ This dividing line, though somewhat arbitrary, makes a plausible division of the distribution of inputs and gives results, as it turns out, that fall reasonably in between the Fed and regression estimates.

\section{THE DATA AND METHOD OF ESTIMATION}

My estimation of inflation imported from abroad involved several steps. First, it was necessary to construct price indexes of output and of input materials for individual industries. This was done for fifty-four industries covering three-fourths of the manufacturing sector. The prices were wholesale product prices. Second, the lag patterns of the price effects of input materials on output were estimated for each industry, holding wages constant, by quarterly time-series regressions. Third, the price effect of world-traded input goods was calculated for each industry, assuming cost increases were passed through dollar for dollar. The effects of these foreign-induced price increases in each industry were then fed through an input-output matrix, allowing for lags, to derive the second and subsequent-round increases in output prices, which incorporate the higher costs passed on by intermediate products to other industries. From the cumulative price effects in each industry, a quarterly index of output prices was derived for the manufacturing sector for comparison with the actual index.

The first step of constructing price indexes is described in Appendix A. For the second step, a quarterly regression for each industry was used to estimate the time

\footnotetext{
5This study also presented results of a simulation of the full Federal Reserve model for import and export price effects, and the estimated increase in consumer prices was the same as the input-output estimate for import price effects alone: the additional demand effects in the model simulation offset the export price effects. However, the model simulation raised the contribution of the $197 \mid$ devaluation to the total rise in consumer prices from 4 percent to 15 percent.

'These fractions. it may be noted. do not provide a basis for allocating the determination of a price partly abroad and partly domestically. That the U.S. domestic supply of a product that is imported or exported was 50 percent. for example. does not mean that its price is determined half abroad and half domestically: the foreign 50 percent may' represent a large or small part of the world market. Moreover. since in most cases there is little or no difference between the foreign and domestic price of a product. it cannot be said that 50 percent of the same increase in price was determined abroad and the remainder domestically.
} 
pattern of effects of total materials costs on output prices, holding straight-time hourly earnings constant. ${ }^{7}$ The period of fit was third-quarter 1968 to first-quarter 1975. World-traded and domestic materials costs were assumed to have the same lag effects and were combined. Earnings were expressed as the percentage change over the preceding four quarters; its regression coefficient was predetermined to be equal to the ratio of employee compensation to total shipments in the industry. The lag patterns for materials costs were constrained to a length of three quarters, based on preliminary experimentation that indicated that this length was sufficient to cover the main effects. Three separate variables were therefore used for materials costs, one the percentage change for the concurrent quarter and one each for the two preceding quarters; the sum of their regression coefficients was constrained to equal the ratio of intermediate inputs to total shipments in the industry. These coefficients form the lag patterns for input prices. These patterns were used to distribute the effects of cost increases over time, but they do not influence the cumulative effect beyond the three quarters of the lag. The lag estimates are given in [4].

The price increases of each industry in response to higher prices of world-traded input materials work to raise input costs to other industries. These in turn produce higher costs for other industries, and so on. The cumulative effects of the initial cost increases can be derived with the use of the inverted input-output matrix redefined to cover the fifty-four industries. The details of the derivation are described in Appendix B. The cumulative effects on the output prices of the individual industries were combined into a weighted index for the manufacturing sector. The weights were the contribution of each industry to final demand in the 1967 input-output matrix. ${ }^{8}$

For the cumulative effects derived here, changes in prices of world-traded inputs were treated as exogenous and as given by the indexes constructed for these items, prices of all other input materials purchased from uncovered industries were assumed to change in the same proportion as the prices of the inputs purchased from the fifty-four covered industries, and prices of all other inputs (services, labor, and other value-added items) were assumed not to change.

The assumption of no price change for service inputs and value-added items is important and would alter the results substantially if relaxed. The multiplier effect of an initial cost increase is raised without limit as the feedback expands. If wages rose in proportion to the cost of living without a lag, the cumulative multiplier would be quite large. The multiplier is moderate-about two-when it is confined as here to the feedback from materials prices only. An important difference between materials prices and wages is that the latter are generally constrained by explicit

\footnotetext{
${ }^{7}$ Straight-time hourly earnings were calculated by dividing BLS worker weekly payrolls by hours and assuming that overtime hours were paid time and a half. The BLS kindly supplied unpublished overtime hours for some of the industries. The series for four-digit SIC industries, weighted by 1967 gross output. were adjusted to the coverage of industries used here.

${ }^{8}$ The 196710 matrix was reconstructed to conform to the coverage of industries for the price indexes. Secondary outputs were not transferted to the primary producers of each product, as is done in the published tables, but were left as part of the output of the original producing industry. The reason was to reffect the actual production in each industry, on which the materials inputs are based. including the production of joint products.
} 
or implicit contracts that delay their adjustment to unanticipated cost-of-living increases. Whereas the policy of accommodation assumes that higher materials costs are quickly passed through to output prices, the assumption to be made about nonmaterials costs, particularly wages, is not clear. Certainly not all feedback effects via wages can be accommodated, since some foreign price increases imply a fall in real wages. The measure here pertains to a limited policy in which no increases in nonmaterials costs are accommodated.

\section{ESTIMATES OF IMPORTED INFLATION}

Table 1 gives the cumulative effects of world-traded inputs on output prices (equation (4) in Appendix B) for the covered manufacturing sector. The worldtraded input prices were held constant after fourth-quarter 1974 and the contribution calculated a year beyond in order to capture all of the lagged effects. Their contribution continued to raise output prices for several quarters after the end of 1974. The input costs have a lagged effect covering three quarters, though most of the effect occurs in the first two. The lag tends to stretch out their contribution to output prices.

World-traded input prices rose twice as fast as output prices, as shown by the rates of change at the bottom of Table 1 . It was the more rapid rise of the world-traded input prices that fostered the view that the escalation of inflation in 1973-74 was in part imported from abroad, and this in turn raised the issue of accommodation. The large increase in world-traded input prices produced, over the period as a whole, a substantial cost-push effect on output prices. The rise of

\section{TABLE 1}

Price Indexes of World-Traded Goods and Their Contributions to the Manufacturing SECTOR PRICE INDEX 1972-75

\begin{tabular}{|c|c|c|c|c|c|c|c|}
\hline & \multirow{2}{*}{$\begin{array}{l}\text { Price Index of } \\
\text { World-Traded } \\
\text { Goods }\end{array}$} & \multicolumn{5}{|c|}{ Effecl on Manufacturing Index of World-Traded Goods } & \multirow{2}{*}{$\begin{array}{c}\text { Manufac } \\
\text { turing } \\
\text { Index }\end{array}$} \\
\hline & & Foods & $\begin{array}{c}\text { Foreign } \\
\text { Petroleum }\end{array}$ & $\begin{array}{l}\text { Combined } \\
\text { Foods and } \\
\text { Petroleum }\end{array}$ & Other & Totai & \\
\hline 1972. I & 100.0 & 100.0 & 100.0 & 100.0 & 100.0 & 100.0 & 100.0 \\
\hline II & 101.6 & 101.2 & & 101.2 & 100.1 & 101.3 & 100.9 \\
\hline III & 106.9 & 102.2 & & 102.2 & 100.2 & 102.4 & 101.7 \\
\hline IV & 115.6 & 105.5 & & 105.5 & 100.9 & 106.4 & 103.1 \\
\hline 1973. I & 125.2 & 106.8 & 100.0 & 106.8 & 101.5 & 108.4 & 106.7 \\
\hline II & 157.7 & 107.1 & 100.4 & 107.5 & 103.1 & 110.8 & 109.6 \\
\hline III & 155.6 & 107.0 & 100.6 & 108.3 & 105.4 & 114.2 & 111.0 \\
\hline IV & 165.0 & 106.9 & 101.9 & 108.9 & 105.6 & 115.0 & 114.2 \\
\hline 1974. I & 192.4 & 108.2 & 103.7 & 112.2 & 104.5 & 117.2 & 121.6 \\
\hline II & 189.9 & 108.6 & 104.4 & 113.4 & 104.4 & 118.4 & 128.3 \\
\hline III & 212.1 & 108.8 & 104.5 & 113.7 & 104.7 & 119.1 & 137.0 \\
\hline IV & 213.4 & 108.9 & 104.6 & 113.9 & 104.8 & 119.4 & 141.2 \\
\hline 1975. IV & & 108.9 & 104.7 & 114.0 & 105.1 & 119.8 & \\
\hline \multicolumn{8}{|c|}{ Annual Rates of Change (percent) } \\
\hline $1973-74$ & 35.9 & 1.6 & 2.3 & 3.9 & 1.9 & 5.9 & 17.0 \\
\hline
\end{tabular}


world-traded input prices of 113.4 percent from 1972 to 1974 raised output prices 19.8 percent, which was half of the actual rise in the manufacturing index of 41.2 percent. Foods and foreign petroleum together accounted for three-fourths of this effect. Although metals were also thought to be an important contributor to the inflationary outburst of 1973 , most of them have a world-traded fraction less than 20 percent, and those with a fraction of 20 percent and above accounted for only 1.2 percentage points (not shown separately) of the rise in the manufacturing index.

The table shows a larger effect of world-traded inputs than the actual rise in the manufacturing index until the end of 1973. Apparently food prices, the main contributor in 1972-73, had a smaller or slower effect than is estimated here.

The table shows the effect of the entire increase in world prices. If we suppose that general inflationary pressures stemming from worldwide growth in aggregate demand were responsible for an equal rise in prices of world-traded and domestic goods, only the additional price increases of world-traded goods can be attributed to a separate international influence on prices. From this point of view, we may determine what the rise in prices would have been had the separate international developments been absent. The ratio of the effect on output prices to the initiating increase in world-traded input prices in 1972-74 was 19.8/113.4 (Table 1). We may apply the same proportional effect to the part of these world price increases that was in excess of the general inflation. If the same basic rise in prices $B$ applied to both world and domestic goods, we may adjust the actual manufacturing rise of 41.2 percent as follows:

$$
B=41.2-(113.4-B) 19.8 / 113.4
$$

The basic increase $B$ was therefore 25.9 percent. The additional increase of world prices of $(113.4-25.9=) 87.5$ percent raised output prices an additional $(87.5$ $\times 19.8 / 113.4=$ ) 15.3 percent or four-tenths $(15.3 / 41.2)$ of the total increase.

This result pertains to manufactured goods and therefore is somewhat higher than would be a comparable contribution to the output of all sectors including services, for which world-traded inputs are fewer. Hence this estimate suggests a somewhat smaller contribution than the one-half obtained by most of the regression studies that pertained to consumer prices. It is somewhat larger than the Federal Reserve estimate, but the latter excluded world-traded inputs that are exported and pertained to consumer prices and a slightly earlier period. Based on the relation between imports and exports for the input materials covered in the present study (exports are three-fourths of imports by input weight), we may conjecture that the Fed study, if expanded to cover exports, would have found the foreign contribution to be three-fourths greater than the 28 percent reported or about 50 percent, similar to the regression studies. However, the Fed study treated the price increases of all imports greater than the ongoing rate of inflation as exogenous to the U.S. economy. which surely leads to an overestimate. The lower estimate of the present study, therefore, seems to be in the right direction.

If the comparison between the present input-output estimate and those from other 
studies is valid, we may conclude that the passing through of higher input costs from world-traded materials as defined here accounts for a large part but not all of the foreign effect estimated in the regressions. The foreign influence in 1973-74 was therefore mainly an effect of world prices on production costs. The regressions apparently picked up an additional effect on the aggregate demand for domestic products and part of the feedback on wages. It is doubtful that a policy of accommodation would want to include these additonal effects, though whether it could avoid doing so is another question.

The increases in costs due to foreign developments had a multiplier effect on domestic output prices. World-traded prices rose 113.4 percent in 1972-74 as noted. These products comprised 18.8 percent of total input materials in the covered industries, as shown by Table 2 in Appendix A, and such inputs were 54 percent of the value of total shipments. Hence the foreign-induced increases in costs were $(113.4 \times 0.188 \times 0.54=) 11.5$ percent, and they raised output prices 19.8 percent or by a multiple of 1.7. Any accommodation of materials-cost increases with a similar set of input weights, therefore, would result in a rise of output prices by almost twice the average cost increase.

\section{SUMMARY AND SOME CONCLUSIONS}

Proposals to accommodate inflation due to foreign influences presume a response of prices that is faster for supply than for demand effects. Accommodation pertains to direct foreign influences on prices from the supply side, and presumably not to indirect effects on domestic aggregate demand, which it is the usual objective of demand management to stabilize.

How much of the 1973-74 inflation should have been accommodated under such proposals is not clear. The present study estimated the cumulative increase in an index of U.S. manufacturing prices (covering three-fourths of the manufacturing sector) that was due initially to price increases of world-traded materials. World price increases from first-quarter 1971 to fourth-quarter 1974 raised the manufacturing index by 20 percent, which was half the actual increase. Three-fourths of that contribution was due to foods and foreign crude petroleum. But part of the increases in world prices reflected the ongoing inflation and did not contribute to its escalation. When we allow for a common rate of inflation, their contribution in excess of the common increase was 15 percent or four-tenths of the total increase. This estimate pertains to the manufacturing sector. A comparable estimate for the entire economy would be somewhat lower. This is a rough estimate; a precise measurement of foreign-price influences does not appear possible.

These results appear reasonably consistent with a similar Federal Reserve study and dissimilar regression estimates and suggest an interpretation of the differences. The Fed estimate was lower because it pertained to all consumer prices but mainly because it excluded input materials that are partly exported. A rough correction for this exclusion makes the Fed estimate higher than the four-tenths of the present 
study, a difference attributable to the treatment in the Fed study of the prices of all imports as exogenous. The regression estimates were higher, apparently because they included some demand effects and feedback on service prices and wages.

Based on the present estimate, accommodation of imported inflation, if confined solely to the direct foreign-price effects on input-materials costs and their multiplier of about two, would have supported about four-tenths of the total rise in manufacturing prices in 1973-74 and somewhat less of the rise in consumer prices. Since consumer prices rose more than twice as fast in 1973-74 as in 1971-72, accommodation of the previous trend rate of inflation plus about four-tenths of the total rise in prices owing to the foreign influences required monetary support for almost a doubling of the inflation rate in 1973-74. Whether intentionally or not, it does appear that, despite the severe 1973-75 recession, most of the spurt in the level of prices in 1973-74 was eventually accommodated. Whether it was desirable, whether a nonaccommodating policy could have been successfully pursued, and the consequences for future expectations of inflation of adopting an accommodating policy are questions that have yet to be resolved.

\section{APPENDIX A}

\section{Price Indexes for 54 Manufacturing Industries}

Quarterly indexes were constructed for two-digit manufacturing industries based on the 1967 input-output tables of the Bureau of Economic Analysis. ${ }^{9}$ Because of the absence of prices for many products and the desire to avoid overlap between the input and output price indexes for the same industry, the BEA industries were redefined to obtain the most appropriate classification [4]. The redefined industries represent 76 percent of total gross output in 1967 of manufacturing sectors 14 through 64 of the BEA input-output matrix. Even after redefinition, the price indexes for many industries are at best only crudely representative of the total inputs or output of the industry. The overall results will be reasonably reliable if the errors of omission tend to cancel out.

Output prices. The wholesale product prices at the seven-digit level of the Bureau of Labor Statistics pertaining to manufacturing were all assigned to four-digit SIC industries. Within four-digit industries the prices were weighted by their relative importance in the BLS index for December 1971. The four-digit indexes were combined into two-digit IO industry series according to gross output in the $1967 \mathrm{IO}$ tables. The error produced by combining weights for different years, 1967 and 1971, should not be serious. Gaps in the individual price series over the period covered were filled by interpolation or linking to comparable series when available.

Input prices. The construction of the input-price indexes began with 1974 weights used by the BEA for its annual deflators of intermediate input prices for

\footnotetext{
${ }^{9}$ All data series were constructed for the period tirst-quarter 1968 to first-quarter 1975 for use in the lag regressions. The estimate of foreign influences used data after first-quarter 1972 only:
} 
each industry. ${ }^{10}$ The BEA weights pertain to general classes of inputs and were decomposed as far as was possible into specific materials according to the value of inputs reported in the 1967 Census of Manufactures for four-digit industries. The basis of the input weights is therefore a cross between 1967 and 1974 values. A tentative set of weights was constructed from these two sources. Inputs of industries not reported in the census or input amounts not reported in a usable form were not represented in the weights. In effect, the disregarded four-digit industries were assumed to use inputs in the same porportions as did the covered four-digit industries in the same two-digit IO industry.

The wholesale product prices were then assigned to this tentative set of weights. All wholesale price series that appeared to be a reasonable match or proxy for an input material were used. Where two or more series were appropriate for a particular input, they were combined by their BLS weights for December 1971 and used as one series. Series were used as inputs for all the industries in which they were appropriate, except that, as previously noted, overlap was avoided by omitting manufacturing price series as inputs into the industry in which they served as part of the output index. The input series use 419 of the 2500 -odd wholesale price series at the seven-digit level. As with the output indexes, the input-price series were interpolated, linked, and if necessary dropped, for periods in which gaps existed. The BLS kindly provided data for gaps in publication of some series for the earlier years. Where no price series was available for a particular input, the weight for that input was dropped and absorbed by the others. The final set of weights represented the relative importance of the input prices included.

Construction of indexes of materials costs in production presents difficulties; since many prices for important materials and the volume of specific inputs in many industries are not available. The indexes constructed were made as comprehensive as the available data permitted and, though the best that appear possible at present, for some of the industries the coverage is extremely poor. It is not known how the exclusion of some prices affects the indexes. We might conjecture that the available prices tend to overrepresent more homogeneous commodities sold in active markets. They may therefore tend to be more volatile than prices of the unrepresented commodities. If so, the input-price indexes exhibit excessive amplitude of fluctuation.

Prices of world-traded input materials. Each input price was classified according to the fraction of its total domestic supply that is imported or exported. The fraction pertains to 1971 and is from the Bureau of the Census [2], supplemented in some cases from other sources. Where the fraction for a particular input was not available, the figure for the aggregate group of which it is part was used. The distribution of these fractions for all input prices is shown in Table 2. A fraction of 20 percent or above was selected as indicating that a product was world traded and

\footnotetext{
"The BEA kindly supplied their deflator weights. The BEA price series were not used in this study. because they are annual series only. and were not used even as annual benchmarks because their coverage is far less detailed than is desired.
} 
its price entirely determined abroad. This is the fraction for grains, an important contributor to inflation in 1973; furthermore, the weight in input indexes of products just below this cutoff figure is small. The prices of these world-traded products are not necessarily entirely determined abroad: the degree of determination undoubtedly differs among them. No other ready method of selection appeared preferable. however. The value of these world-traded products comprises 10 percent of the value of shipments of the fifty-four industries. "

\section{TABLE 2}

Distribution of InPut Prices by Degree They Are World Traded

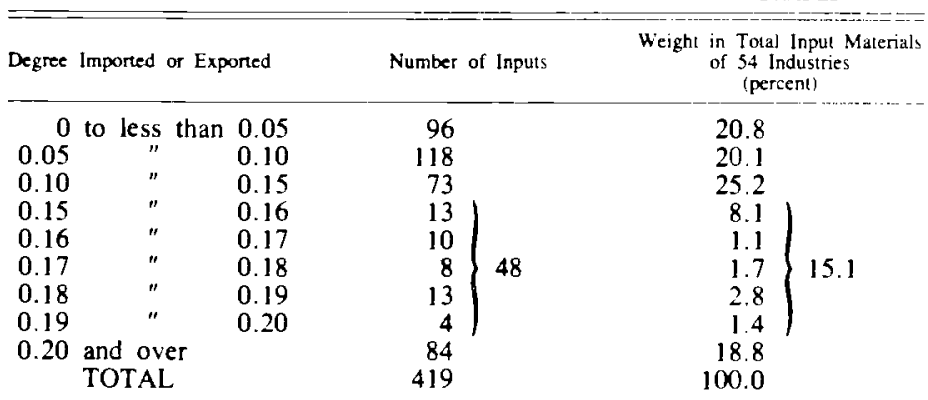

The monthly changes in world-traded prices in each industry. scaled by their input weight, were divided by the corresponding monthly total input-price index to give the part of the percent change in input prices attributable to world-traded goods. The monthly percent changes were cumulated to derive the quarterly percent changes used in the analysis. The index for world-traded inputs may inperfectly reflect prices actually paid. even more than is usual for reported prices of domestic products, because of differences between domestic and world price quotations for the same product. (Because of the importance of changes in price of imported crude petroleum in 1973-74, the domestic BLS price was replaced by the refineryacquisition cost of imports of this commodity $[6, p$. 17]. Its input weight in the petroleum industry was set at the 1974 world-traded fraction of 30 percent rather than at the 1967 fraction of 13 percent. ${ }^{12}$ )

The proportion of domestic and world-traded goods actually included in the indexes affects the division of input-price changes into domestic and world sources. If a particular input is not priced by the BLS, it is not covered in our input-price indexes, even though it may be an important domestic or world-traded item.

${ }^{1 " T h e ~ w o r l d-t r a d e d ~ p r o d u c t s ~ c o m p r i s e ~} 18.8$ percent by weight of total input materials. as show $n$ in Tabie 2. Total input materials as a percentage of total shipments average (by final demand weights) 54 percent in the covered industries. World-traded inputs as a fraction of shipments are therefore 10.188 $\times 0.54=10.2$ percent.

The coverage of imports and exports can be found by calculating the total weight in output of the world-traded fraction for all inputs. This weight is 7.3 percent. The percentage of imports and exports in total shipments in the input-output table for these industries is 6 . 0 percent. so the coverage is slightly too high.

${ }^{12}$ According to data collected by Avram Kisselgoff as part of his National Bureau study of oil prices. imported crude comprised 30 percent of total domestic consumption by value at the end of 1974. 
Omissions are therefore important, though they do not clearly bias the indexes one way or the other.

\section{APPENDIX B}

\section{The Cumulative Effect of Price Increases of Inputs}

The output price of industry $i$ at time $t, P_{i}$, can be viewed as determined identically by its value-added costs, $v_{i t}$, and the prices of inputs from all other industries. Let $a_{i j}$ be the weight in the output of industry $i$ of the input from industry $j$. The effects of input price changes are distributed over three quarters as estimated. The lagged effects of the concurrent and two previous quarters in industry $i$ may be denoted by $f_{i 1}, f_{i 2}, f_{i 3}$, which are constrained to total unity. Then for industry $i$ the output price can be expressed as

$$
P_{i t}=v_{i t}+f_{i 1} \sum_{j} a_{i j} P_{j t}+f_{i 2} \sum_{j} a_{i j} P_{j t-1}+f_{i 3} \sum_{j} a_{i j} P_{j t-2} .
$$

It may be noted that the effect of the input from an industry's own output, $a_{i i}$, is not zero inasmuch as the industries are broadly defined and output from one part is used in other parts. Also, some firms use some of their own production as an input.

By definition, for each industry $i$, the weight of inputs from industries covered in our schema plus the contribution of inputs from industries not covered (comprising nonmanufacturing and, for want of price data, some manufacturing industries) and of the value added items sums to unity. The assumption was made that prices of labor and other value-added items, purchased services, and imports are not affected by feedback, but all other uncovered input prices have the same percentage change as the prices of covered inputs. This was accomplished for each industry by raising the weights of the inputs $a_{i j}$ from the covered industries 1 to $n$ by $h_{i}$, where

$$
h_{i} \sum_{j}^{n} a_{i j}=1-\frac{v_{i}+\text { (services and imports per unit) }}{P_{i}} .
$$

The effect of a rise in the prices of world-traded goods is derived in two steps. First, the initial effect on industry prices is found by deriving the increase in materials costs due to price increases of world-traded goods. Second, given the initial rise in prices for each industry, the effect on all industries is given by equation (1). The equation is solved recursively to give the effect from quarter to quarter.

The solution can be presented in simple terms with the use of matrix notation. Since the value-added items and service prices are assumed constant, their change is zero. The lag terms form a set of three diagonal matrices, where the matrix $\mathbf{F}_{1}$ has a main diagonal of $f_{11}, f_{21}, \ldots, f_{n 1}$ and zeros elsewhere, and similarly for $\mathbf{F}_{2}$ and 
$\mathbf{F}_{3}$. The adjustment factors $h_{i}$ in (2) form a similar diagonal matrix $\mathbf{H}$. Denote $\mathbf{F}_{\mathrm{k}} \mathbf{H}$ by $\mathbf{L}_{\mathbf{k}}$. The matrix of direct requirements of output for inputs from the $n$ covered industries is $\mathbf{A}=\left\{a_{i j}\right\}$. The rate of change of output prices for the $n$ covered industries forms a column vector denoted $\dot{\mathbf{P}}_{r}$. The equation of price changes in matrix notation can then be written

$$
\dot{\mathbf{P}}_{t}=\mathbf{L}_{1} \mathbf{A} \dot{\mathbf{P}}_{t}+\mathbf{L}_{2} \mathbf{A} \dot{\mathbf{P}}_{t-1}+\mathbf{L}_{3} \mathbf{A} \dot{\mathbf{P}}_{t-2}
$$

The initial effect on the output price of each industry of price increases in world-traded goods $\dot{w}_{i t}$ may be represented by the column vector $\dot{\mathbf{W}}_{t}$. The elements $\dot{w}_{i t}$ are the contribution of world-traded goods to percentage changes in input materials costs for each industry, scaled by the weight of input materials in the output of the industry. To incorporate these effects, we add $\mathbf{F}_{1} \dot{\mathbf{W}}_{t}+\mathbf{F}_{2} \dot{\mathbf{W}}_{t-1}$ $+\mathbf{F}_{3} \dot{\mathbf{W}}_{t-2}$ to the above equation and solve for $\dot{\mathbf{P}}_{t}$ to obtain

$$
\begin{aligned}
\dot{\mathbf{P}}_{t}= & \left(\mathbf{I}-\mathbf{L}_{1} \mathbf{A}\right)^{-1}\left(\mathbf{L}_{2} \mathbf{A} \dot{\mathbf{P}}_{t-1}+\mathbf{L}_{3} \mathbf{A} \dot{\mathbf{P}}_{t-2}+\mathbf{F}_{1} \dot{\mathbf{W}}_{t}\right. \\
& \left.+\mathbf{F}_{2} \dot{\mathbf{W}}_{t-1}+\mathbf{F}_{3} \dot{\mathbf{W}}_{t-2}\right),
\end{aligned}
$$

where $I$ is the identity matrix.

An overall price change $C_{t}$ is found by averaging the industry changes, each weighted by its share of final demand, $\mathbf{S}=\left(s_{1}, s_{2}, \ldots, s_{n}\right)$,

$$
\dot{C}_{t}=\mathbf{S} \dot{\mathbf{P}}_{t} .
$$

At the conclusion of the time sequence of these effects, $t=T$, the price index $C$ is the accumulation of all the intervening quarterly changes,

$$
C_{T}=\prod_{t=0}^{T}\left(1+\dot{C}_{t}\right)
$$

The total effect of a one-time change in input prices $\dot{\mathbf{W}}_{o}$ may be written

$$
\mathbf{P}_{T}=\mathbf{F}_{1} \mathbf{H A P} \mathbf{P}_{T}+\mathbf{F}_{2} \mathbf{H A P} \mathbf{P}_{T}+\mathbf{F}_{3} \mathbf{H A} \mathbf{P}_{T}+\mathbf{F}_{1} \dot{\mathbf{w}}_{o}+\mathbf{F}_{2} \dot{\mathbf{W}}_{o}+\mathbf{F}_{3} \dot{\mathbf{W}}_{o} .
$$

Since $\mathbf{F}_{1}+\mathbf{F}_{2}+\mathbf{F}_{3}=\mathbf{I}$, we have

$$
\mathbf{P}_{T}=(\mathbf{I}-\mathbf{H A})^{-1} \dot{\mathbf{W}}_{0} \text {. }
$$

Suppose, as an example, all industries were the same size, used the same fraction of world-traded goods, and all $\dot{w}_{i 0}$ were the same because of a devaluation of the currency. The overall change would be the same for each industry:

$$
C_{T}=P_{i T}=\frac{\dot{w}_{i o}}{1-h_{i} \sum_{j} a_{i j}}
$$


The reciprocal of the denominator gives the multiplier of the long-run effect of $\dot{\mathbf{w}}$ on P. For the manufacturing industries the average $h_{i} \Sigma_{j} a_{i j}$ for all $i$ is 0.543 and the multiplier is 2.19 .

\section{LITERATURE CITED}

1. Berner, Richard, Peter Clark, Jared Enzler, and Barbara Lowrey. "International Sources of Domestic Inflation." Joint Economic Committee, Studies in Price Stability and Economic Growth (94th Cong., 1st sess.), paper no. 3 (5 August 1975).

2. Bureau of the Census. U.S. Commodity Exports and Imports as Related to Output for 1971. January 1974.

3. Bureau of Labor Statistics. Wholesale Prices and Price Indexes, Supplement 1972. February 1973.

4. Cagan, Phillip. "Appendix Tables to Imported Inflation 1973-74." National Bureau of Economic Research, 1978, processed (available on request from author).

5. - "Monetary Problems and Policy Choices in Reducing Inflation and Unemployment." In Contemporary Economic Problems, edited by William Fellner, pp. 17-53. Washington, D.C.: American Enterprise Institute, 1976.

6. Department of the Interior. Bureau of Mines Minerals Yearbook, Crude Petroleum and Petroleum Products. 1974.

7. Dewald, William G., and Maurice N. Marchon. "International Prices and Exports in 'St. Louis' Models of Canada, France, Germany, Italy, the United Kingdom, and the United States." Ohio State University College of Administrative Science, Working Paper Series 77-17 (May 1977), processed.

8. Fair, Ray C. "Inflation and Unemployment in a Macroeconometric Model." Paper presented at Federal Reserve Bank of Boston Conference, 14-16 June 1978, processed.

9. Goldstein, Morris. "Downward Price Inflexibility, Ratchet Effects, and the Inflationary Impact of Import Price Changes, Some Empirical Tests." IMF Staff Papers, 24 (November 1977), 569-612.

10. Hamburger, Michael. "Behavior of the Money Stock: Is There a Puzzle?" Journal of Monetary Economics, 3 (July 1977), 265-88.

11. Keran, Michael, and Michael Riordan. "Stabilization Policy in World Context." Federal Reserve Bank of San Francisco, Economic Review' (Fall 1976), 5-19.

12. Levy, Michael E. "International Influences on U.S. Inflation 1971-76." U.S. Department of Commerce, Bureau of International Economic Policy and Research, March 1978.

13. Modigliani, Franco, and Lucas Papademos. "Monetary Policy for the Coming Quarters: The Conflicting Views."' Federal Reserve Bank of Boston, New England Economic Review (March/April 1976), 2-35.

14. - "Target for Monetary Policy in the Coming Year." Brookings Papers on Economic Activity (1975), 141-63.

15. Phelps, Edmund S. "Creating Money for Tax Rebates." New York Times (26 January 1975), Op-ed page.

16. Rasche, Robert M., and John A. Tatom. "The Effects of the New Energy Regime on Economic Capacity, Production, and Prices." Federal Reserve Bank of St. Louis, Review, 59 (May 1977), 2-12.

17. Tobin, James. "Monetary Policy and the Control of Credit." In Answers to Inflation and Recession: Economic Policies for a Modern Society, edited by Albert T. Sommers. New York: The Conference Board, 1975. 
18. Weintraub, Robert E. The Impact of the Federal Reserve System's Monetary Policies on the Nation's Economy. Staff Report of the Subcommittee on Domestic Monetary Policy of the Committee on Banking, Currency and Housing, House of Representatives (94th Cong., 2d sess.), December 1976. 